\title{
Becoming-Democratic as Becoming-Revolutionary
}

\section{Raniel SM. Reyes}

\begin{abstract}
I explain in this paper how Deleuze and Guattari's philosophy of becoming-minoritarian functions as a principle of becoming-revolutionary. To achieve this goal, I elucidate one of the significant features of becoming-minoritarian-becoming-democratic. The said principle is one of the ways that shows how to become revolutionary against the capitalist-captured democracy. I elaborate this undertaking by explicating becoming-democracy's antithetical stance to conventional democratic practices and popular opinions, as well as its violence to the human condition. Ultimately, becomingdemocracy exemplifies the principle of becoming-revolutionary via its critical diagnosis of different capitalist and democratic codifications in the society. Such mode of resistance fuels philosophy's political vocation - the creation of concepts capable of radicalizing the grain towards a people and world-to-come.
\end{abstract}

Keywords: becoming-minoritarian, becoming-democratic, becomingrevolutionary, capitalism

\section{Prelude: Micropolitics and Becoming-Revolutionary}

side from the celebrated May 1968 political struggle, Deleuze and
Guattari's micropolitics is greatly informed by Classical Marxism,
Leninism, and the Bolshevik Revolution, to name a few. Nevertheless, while the concept of the Communist revolution is perceived to inform their sociopolitical imagination, its proletarization of the revolution and teleological trajectory are criticized from the point of view of a micropolitical configuration of a revolution-to-come or becomingrevolutionary.

Deleuze and Guattari repudiate the possibility of a global revolution against totalitarian and capitalist-manipulated States whose goal is to end all contradictions in society. Likewise, they negate any kind of macropolitical 
struggles that would convert ethical or micro-fascism ${ }^{1}$ into molecular investments of free-floating desire. For them, it is imperative to launch a micropolitical diagnosis of the molecular existence of fascism in contemporary institutions, as well as in the manifold networks of political and subcultural enunciations. Its creative mutations in these social spaces transform this brand of fascism into a transhistorical phenomenon. Its transhistoricality makes fascism a very hazardous phenomenon. In $A$ Thousand Plateaus, they explain that: "What makes this fascism dangerous is its molecular or micropolitical power, for it is a mass movement: a cancerous body rather than a totalitarian organism." 2 In Chaosophy, Guattari adds:

The historical transversality of the machines of desire on which totalitarian systems depend is ... inseparable from their social transversality. Therefore, the analysis of fascism is not simply a historian's specialty. I repeat: what set fascism in motion yesterday continues to proliferate in other forms, within the complex contemporary social space. ${ }^{3}$

The molecular nuances of fascism in contemporary social spaces incapacitate any macropolitical interventions or examinations. Unlike macropolitics, Deleuzo-Guattarian micropolitics is concerned with critical and active experimentation with the numerous angles and fissures existing between politico-economic institutions or investments and subinstitutional movements of desire. ${ }^{4}$ As such, they support the political function of the minoritarians by virtue of their ability to antagonize the molar social codes, subjecting majoritarian norms toward transfiguration. The minoritarians' capacity for deterritorialization is the essence of revolutionary becoming. Moreover, included in the principle of becoming-minoritarian is the goal of inventing novel investments and subjectivities capable of destabilizing the status quo.

\footnotetext{
${ }^{1}$ In Foucault's Preface to Anti-Oedipus, he distinguishes two kinds of fascism: historical fascism and ethical or micro-fascism. He associates the former with the fascism of Hitler and Mussolini. On the other hand, he characterizes the latter as "the fascism in us all, in our heads and in our everyday behavior, the fascism that causes us to love power, to desire the very thing that dominates and exploits us." Michel Foucault, Preface to Gilles Deleuze and Felix Guattari, Anti-Oedipus: Capitalism and Schizophrenia, trans. by Robert Hurley, Mark Seem, and Helen R. Lane (Minneapolis, MN: University of Minnesota Press, 1983), xii.

${ }^{2}$ Gilles Deleuze and Felix Guattari, A Thousand Plateaus: Capitalism and Schizophrenia, trans. by Brian Massumi (Minneapolis: University of Minnesota Press, 1987), 236.

${ }^{3}$ Felix Guattari, Chaosophy: Texts and Interviews 1972-1977, ed. by Sylvère Lotringer, trans. by David L. Sweet, Jarred Becker, and Taylor Adkins (Los Angeles, CA: Semiotext(e), 2009), 236.

${ }^{4}$ Cf. Paul Patton, Deleuze and the Political (London: Routledge, 2000), 7.
} 
According to Deleuze and Guattari, a 'concept' is an openmultiplicity. In What Is Philosophy?, they argue that it is a "specifically philosophical creation [which] is always a singularity." 5 Speaking of multiplicities and singularities, then a concept is likewise an assemblage the components of which consist of concepts. ${ }^{6}$ Its relations with other concepts are very significant for its identity-formation and meaning. Moreover, they define philosophy as the active creation or invention of concepts that radically transfigure economic, political, and historical occurrences that thwart life's possibility of becoming-other. ${ }^{7}$ In this vein, through a concept (philosophical concept), we can vigorously overcome our experiences toward novel kinds of thinking and living. Philosophical concepts, for them, "are fragmentary wholes that are not aligned with one another so that they fit together, because their edges do not match up. They are ... the outcome of throws of the dice." 8

Micropolitics is a philosophical concept whose workings can only be understood when problematized in relation to another philosophical concept, namely, becoming-revolutionary. Their dynamic hybridity (in conjunction with other concepts such as becoming, multiplicities, deterritorialization, among others) crafts new intensities, connections, and possibilities of life that escape capitalism's molar codification and the State's capture. Meanwhile, the concept, becoming-revolutionary is untimely. It does not only aid micropolitics in the molecular reinstatement of desire, for instance; rather, it also subverts all molar codes or majoritarian representations (under capitalist or state capture) that derail rhizomic movements of desire, as well as the endless creation of nomadic and productive forces in society. In Deleuze and the Political, Patton elucidates the principle of becoming-revolutionary: "Becoming-revolutionary is a process open to all at any time. Moreover, its value does not depend on the success or failure of the molar redistributions to which it gives rise." 9 This explanation reinforces Deleuze and Guattari's argument: "The victory of a revolution is immanent and consist in the new

\footnotetext{
${ }^{5}$ Gilles Deleuze and Felix Guattari, What Is Philosophy?, trans. by Hugh Tomlinson and Graham Burchell (New York: Columbia University Press, 1994), 7.

${ }^{6}$ The same description of a concept appears in Massumi's Translator's Foreword of $A$ Thousand Plateaus: "A concept is a brick. It can be used to build the courthouse of reason. Or it can be thrown through the window ... Because the concept in its unrestrained usage is a of circumstances, at a volatile juncture ... The concept has no subject or object other than itself. It is an act." Brian Massumi, Translator's Foreword to Deleuze and Guattari, A Thousand Plateaus, xiii.

${ }^{7}$ See Deleuze and Guattari, What Is Philosophy?, 108.

${ }^{8}$ Ibid. 35.

${ }^{9}$ Patton, Deleuze and the Political, 83.
}

(c) 2019 Raniel SM. Reyes

https://www.kritike.org/journal/special issue/reyes april2019.pdf

ISSN 1908-7330

(c) BY-NC-ND 
bonds it installs between people, even if the bonds last no longer than the revolution's fused material and quickly give way to division and betrayal."10

Micropolitics is a new philosophy of immanence based on a politicized philosophy of difference. It is concerned with the transversalities, tensions, and transformations that occur alongside, beneath, and outside the Capitalist/State apparatus. Such a Promethean task is the challenge of the subject groups or the nomads. Because micropolitics is concerned with problems involving performances and pragmatics, not with essences, the question that needs to be asked is: "How does micropolitics or becomingrevolutionary work?" instead of "What does micropolitics or becomingrevolutionary mean?" 11

\section{Becoming-Democratic as Becoming-Minoritarian/Revolutionary}

\section{Minoritarian Politics and the Becoming-Other of Life}

The complex relationship between Deleuze's philosophy of difference and his politics of difference can be clarified by explaining his theory of multiplicities. ${ }^{12}$ Against the backdrop of the philosophy of representation (or all forms of universalization), Deleuze states that "there is always an unrepresented singularity who does not recognize precisely because it is not everyone or the universal." 13 The voiceless or the subaltern is an essential ingredient of minoritarian politics. In Kafka, Deleuze and Guattari assert that every individual or Oedipal issue in a life-story, for example, must be viewed via the lens of the political, which is also in conjunction with other spectra of living (e.g., economic, aesthetic, cultural, and the like). This perspective is magnified in A Thousand Plateaus where they claim that "everything is political, but every politics is simultaneously a macropolitics and a micropolitics." 14

${ }_{10}$ Deleuze and Guattari, What Is Philosophy?, 177. See also Patton, Deleuze and the Political, 83.

${ }_{11}$ As part of their critique in relation to the conventional appropriation of desire through the question "What is desire?" Deleuze and Guattari focus on the query "How does desire work?" Their change of focus, from the essentialist to the functionalist problematic, is a microcosm of their overall critique of all forms of representation.

12 The distinction between majoritarian and minoritarian literature, for instance, must not be perceived in terms of difference in degree; rather, it should be viewed in terms of difference in kind or as two types of multiplicity: extensive or quantitative multiplicity (majoritarian) and intensive or qualitative (minoritarian) multiplicity. A holistic understanding of these two kinds is only possible in relation to the Deleuzian politics of difference in general.

${ }^{13}$ Gilles Deleuze and Claire Parnet, Dialogues, trans. by Hugh Tomlinson and Barbara Habberjam (London: Athlone Press, 1987), 52.

${ }^{14}$ Deleuze and Guattari, A Thousand Plateaus, 213.

(c) 2019 Raniel SM. Reyes

https://www.kritike.org/journal/special issue/reyes april2019.pdf

ISSN 1908-7330

(cc) BY-NC-ND 
Minoritarian politics is a paramount feature of Deleuze and Guattari's "relational understanding of difference." 15 The opposition between minority and majority is complex. Writ large, the majoritarian logic of production derives its regulative principle from a transcendental concept or arborescent principle, which is external to the particularities it produces, and which homogenizes and hegemonizes. The majoritarian resembles a hierarchical and nonreflexive structure because it assumes a leverage over other particularities. According to Deleuze and Guattari: "When we say majority, we are referring not to a greater relative quantity but to the determination of a state or standard in relation to which larger quantities, as well as the smallest, can be said to be minoritarian."16 The "whiteheterosexual-European-male,' for example, is a majoritarian standard. Albeit they are fewer in numbers compared with blacks, Asians, transgenders, women, and the like, 'man' still is designated as the majoritarian model. Man "appears twice, once in the constant and again in the variable from which the constant is extracted. Majority assumes a state of power and domination, not the other way around. It assumes the standard measure,"17

The minoritarian or molecular promotes singular and local connections by virtue of its autopoietic and protean attributes. It also espouses an ethics of prudence, that is, its elucidation of the value of the minorities does not want to commit the similar blunder by the very principle it seeks to critically diagnose. Its specific goal, as Patton argues in Deleuze and the Political, is merely to defend the right of the minorities by expanding the majoritarian standard to include the excluded, and by practicing gender sensitivity and neutrality, as well as multiculturalism. ${ }^{18}$ Hence, joining man are also other concepts such as 'woman,' 'Asians,' 'Africans,' 'homosexuals,' and the like. However, their penchant to the minoritarian is merely a prologue to the third and most important term in micropolitics-becomingminoritarian or molecular.

Before elucidating this concept's significant role in micropolitics or assemblage theory, I deem it necessary to first explicate the Deleuzian notion of becoming - an omnipresent concept in Deleuze's philosophy even before his collaboration with Guattari. Deleuze's philosophy of becoming is greatly Spinozian (affects) and Nietzschean (power). Affects and power are indispensably contributory to schizoanalysis and assemblage theory articulated in Anti-Oedipus and A Thousand Plateaus, respectively. In Spinoza's philosophy, the affective dimension of a body (individual and collective agencies) implies both the capacity to affect another body and the power to

${ }^{15}$ See Patton, Deleuze and the Political, 47.

${ }^{16}$ Deleuze and Guattari, A Thousand Plateaus, 291

${ }_{17}$ Patton, Deleuze and the Political, 105.

${ }^{18}$ See ibid., 47.

(c) 2019 Raniel SM. Reyes

https://www.kritike.org/journal/special issue/reyes april2019.pdf

ISSN 1908-7330

(c) BY-NC-ND 
be affected. As such, the affective aspect of the body or power is parallel to the Nietzschean concept of the will to power. Nietzsche's understanding of power is not about craving for power and the eradication of the weak because these are only expressions of slave morality or the descending life-typology. Relation of bodies can either be active or reactive, or it may increase or diminish an agency's capability to act. Engagement with other bodies increases one's powers. Ideally, the processes involved in the said encounters result in the bodies' creative transformation and not appropriation.

Deleuze perceives the feeling of power as a kind of affect inextricably connected to a process of becoming or becoming-other. ${ }^{19}$ Apparently, implicit in becoming-other is the goal of 'joy' in Spinoza, the active expenditure of power in Nietzsche, and the enrichment of desire via perpetual and creative connections and production in Deleuze and Guattari. Additionally, becoming-other refers to transversalities with other bodies and proximities, or what Bergson calls the realm of the 'nonhuman.' It is the becomingminoritarian of everything.

Becoming-minoritarian resembles Kafka's rhizomatic minoritarian literature. As opposed to being the standard (majoritarian) and being the marginalized (minoritarian), becoming-minoritarian advocates a principle of becoming that operates at the middle of the former and the latter. As Deleuze and Guattari explicate:

A line of becoming ... passes between points, it comes up through the middle, it runs ... transversally to the localizable relation to distant or contiguous points. A point is always a point of origin. But a line of becoming has neither beginning nor end .... The middle is not an average $\ldots$ it is the absolute speed of movement. A becoming is always in the middle .... A becoming is neither one nor two, nor the relation of the two; it is the in-between .... If becoming is a block ... it is because it constitutes a zone of proximity and indiscernibility ... a nonlocalizable relation sweeping up the two distant or contiguous points, carrying one into the proximity of the other. ${ }^{20}$

${ }^{19}$ In A Thousand Plateaus, Deleuze and Guattari explain how affects are related to becomings: "To the relations composing, decomposing, or modifying an individual there correspond intensities that affect it, augmenting or diminishing its power to act; these intensities come from external parts or from the individual's own parts. Affects are becomings." Deleuze and Guattari, $A$ Thousand Plateaus, 256.

${ }^{20}$ Ibid., 293 


\section{BECOMING-DEMOCRATIC AS BECOMING-REVOLUTIONARY}

In Dialogues, the majoritarian, minoritarian, and becomingminoritarian principles are discussed in terms of a triadic politics of immanence. Assemblages are comprehended through these lines that immanently constitute different things, individuals, and groups. For Deleuze and Parnet: "We think lines are the basic components of things and events. So everything has its geography, its cartography, its diagram. What's interesting, even in a person, are the lines that make them up, or they make up, or take, or create." ${ }^{21}$ The intricate nuances and tensions produced through the conjunction and disjunction of these lines are the very objects of study of schizoanalysis, micro-politics, rhizomatics, and cartography. 22

The first is the line of rigid segmentarity (molar line). Modern society or State society bombards us with enormous numbers of rigid lines or striated spaces by which individuals move from one place to another-the line that connects us from the Oedipalized relation in the family to the arboreal structures in the university, compartmentalized setting in the workplace, and the bureaucratic configurations in the government, among others. These lines are characterized by "clearly defined segments, in all directions, which cut us up in all senses, packets of segmentarized lines." 23 Segments are interdependent to social binary opposites such as black and white (race), man and woman (sex), and rightist and leftist (political affiliation). Albeit they are characterized by rigid lines, they collide or cut across each other in various directions and operate diachronically. ${ }^{24}$ Consequently, new lines or binaries are produced such as the transgender identity when man-and-woman binary collides or when you are neither a man nor a woman. Despite their dynamic production, rigid segments are likewise instruments of power. Social segments in the form of social codes are formulated as devices of control and surveillance. Using the prison model (as a microcosm of all other institutions such as the hospital and the factory), Foucault elucidates a macrolevel account of power and its aptitude of disciplinarity. A reconstructed version of Jeremy Bentham's notion of panopticon is the central idea of Foucault's political philosophy in Discipline and Punish. ${ }^{25}$ Through the State's centralized machinery, "each segment is underscored, rectified, and homogenized in its

${ }^{21}$ Gilles Deleuze, Negotiations, trans. by Martin Joughin (New York: Columbia University Press, 1995), 33.

${ }^{22}$ Gilles Deleuze and Claire Parnet, Dialogues II, rev. ed., trans. by Hugh Tomlinson and Barbara Habberjam (New York: Columbia University Press, 2007), 125.

${ }^{23}$ Ibid., 124.

24 See ibid., 128.

25 Bentham's panopticon is very important to Foucault's political philosophy in Discipline and Punish. After 1975, the former's philosophy is no longer relevant to the latter's political philosophy. See Paul Patton, "Foucault and Normative Political Philosophy," in Foucault and Philosophy, ed. by Timothy O'Leary and Christopher Falzon (Oxford: Wiley-Blackwell), 212214.

(c) 2019 Raniel SM. Reyes

https://www.kritike.org/journal/special issue/reyes april2019.pdf

ISSN 1908-7330

(c) ) BY-NC-ND 
own right, but also in relation to the others. Not only does each have its own unit of measure, but there is an equivalence and translatability between units. The central eye has as its correlate a space through which it moves, but it itself remains invariant in relation to its movements." 26

The molar lines that cut across each other also produce fissures. In $A$ Thousand Plateaus, Deleuze and Guattari clarify that instead of establishing the distinction between the segmentary and the centralized, we should elucidate the existing difference between the two kinds of segmentarity, namely rigid (modern) and supple (primitive). ${ }^{27}$ The molecular lines, the lines which operate in primitive societies, are suppler than the molar. Because they are characterized by fluxes and are elusive to all types of overcoding or the State's panoptical control, they bring about molecular becomings. If molar lines operate diachronically between segments to produce more binarized segments, the molecular lines operate at each segment's subterranean plane via disjunctions and conjunctions, or repulsion and attraction. The rhizomic fluxes are "imperceptible, marking a threshold of lowered resistance ... you can no longer stand what you out up with before ... the distribution of desires has changed in us, our relationships of speed and slowness have been modified." 28 Nevertheless, unlike the rhizomic fluxes, traditional binaries retain their existence even though new ones are produced after a series of collisions. Although apparent dissimilarities separate the molar (modern or rigid) from the molecular (primitive or supple) lines, it is important to know why Deleuze and Guattari deem Kafka (the minoritarian writer) as the greatest theorist of bureaucracy. How can a writer espouse rhizomatic thinking and be a theorist of rigid segmentarity at the same time? The modern bureaucratic societies are not only governed by arborescent structures, segmented spaces, and a centralized mechanism, but they are also characterized by "a suppleness of and communication between offices, a bureaucratic perversion, a permanent inventiveness or creativity practiced even against administrative regulations." 29

In the case of fascism, it can exist both in the rigid and the supple segments. Prior to its conversion into a grand, collective, and centralized black-hole of macro-fascism, micro-fascism may exhibit supple segmentarity. Moreover, the molecular is not downsized or individualistic although it operates in fissure and pockets. The distinction between the two therefore is analytic and qualitative, and the relationship between them is characterized by intricate interdependence. In other words, molar and molecular lines coexist. Kafka's minoritarian philosophy, for example, illustrates how the

\footnotetext{
${ }^{26}$ Deleuze and Guattari, A Thousand Plateaus, 211.

27 Ibid., 210.

${ }^{28}$ Deleuze and Parnet, Dialogues II, 126.

${ }^{29}$ Deleuze and Guattari, A Thousand Plateaus, 214.
} 
"barriers between offices cease to be 'a definite dividing line' and are immersed in a molecular medium (milieu) that dissolves them and simultaneously makes the office manager proliferate into microfigures impossible to recognize or identify, discernible only when they are centralizable: another regime, coexistent with the separation and totalization of the rigid segments." 30

Lastly, a line enables us to navigate across our segments and thresholds toward something terra incognita - the 'abstract line.' It resembles the line of flight by which the other kinds of line owe their existence. In this vein, it entails a power to rupture all binaries - be it segmented or suppletoward a becoming-imperceptible. Although the fluidity of the molecular lines actualizes as a device of deterritorialization, the possibility of reterritorializing into molar lines is inevitable. Meanwhile, the abstract line can transfigure into a creative and radical assemblage, as well as the assemblage it affects. In fact, Deleuze and Guattari design and conceive $A$ Thousand Plateaus not only as a rhizomic literature but also as a philosophical piece promoting lines of flight in thinking and living. It is a book that fosters novel and radical pathways of theory and praxis in a way that deterritorialization leads to further deterritorializations, and creation to perpetual creations. ${ }^{31} \mathrm{~A}$ line of flight is relative when it operates in between milieus that are usually pre-established attractors or flows. In this regard, it can reterritorialize into extremely rigid segments, and worse, it can metamorphose into a line of decadence or destruction. Moreover, a line of flight is absolute when it promotes absolute deterritorialization that fashions entirely new relations, ways of thinking, and thresholds. ${ }^{32}$ Mark Bonta and John Protevi, in Deleuze and Geophilosophy, describe the absolute line of flight as a vector of freedom. ${ }^{33}$ As a tool for freedom, Deleuze and Guattari underscore the call for the transfiguration of the lines of flight to become machinic assemblages of incessant enunciation, relation, and overcoming that would radicalize social life as a protean plane of existence, always haunted by the horrifying possibilities of lines of destruction. ${ }^{34}$

As a vector of freedom, the absolute line that fuels the principle of becoming-minoritarian gains a political force because it emancipates the subaltern concepts and entities from the totalizing dominion of the molar line and the highly polymorphous current of the molecular. More importantly, becoming-minoritarian abrades the minoritarian to the majoritarian to

\footnotetext{
${ }^{30}$ Ibid.

${ }^{31}$ See Mark Bonta and John Protevi, Deleuze and Geophilosophy: A Guide and Glossary (Edinburgh: Edinburgh University Press, 2004), 106.

32 See ibid., 106.

33 See ibid.

${ }^{34}$ Deleuze and Guattari, A Thousand Plateaus, 229.
}

(C) 2019 Raniel SM. Reyes

https://www.kritike.org/journal/special issue/reyes april2019.pdf

ISSN 1908-7330

(c) $)$ BY-NC-ND 
extinguish the rigid ramparts of majoritarian, as well as the subaltern frontiers of the minoritarian principle, and differentialize them through incessant deterritorialization.

Becoming-other as becoming-minoritarian is immensely informed by its dynamic and reflexive relation with marginalized social collectivities outside the frontiers of traditional institutions such as the family and the State. They represent "minoritarian groups that are oppressed, prohibited, in revolt, or always on the fringe of recognized institutions." ${ }^{35}$ As a creative process, becoming-minoritarian deterritorializes the minoritarian's determinate configurations in relation to the majoritarian. In the case of the majoritarian 'man' and the minoritarian 'woman,' becoming-minoritarian is tantamount to becoming-woman. All becomings, even the becomingminoritarian of language in its activity of stuttering, should pass becomingwoman, which is another term Deleuze and Guattari utilize to represent becoming-other. In this manner, becoming-woman subjects 'man' and, in fact, even 'woman' into perpetual deterritorialization:

In a way, the subject in a becoming is always 'man,' but only when he enters a becoming-minoritarian that rends him from his major identity. ... Conversely, if ... women must become-woman, if children must become-child ... it is because only a minority is capable of serving as the active medium of becoming, but under such conditions that it ceases to be a definable aggregate in relation to the majority. ${ }^{36}$

Becoming-minoritarian as becoming-woman dismantles conventional woman stereotypes imagined by the male phallic economy in the same manner that it deletes even the essentialist underpinnings and values traditionally associated with women. The audacious efforts of the first wave of feminists, for example, who struggled for equal rights to education and suffrage are indeed praiseworthy. Deleuze and Guattari, however, argue that a molar politics of this kind should be coupled by molecular politics of becoming-woman. ${ }^{37}$ Thus, failure to pass the process would imply their conversion into another kind of majoritarian politics wherein its process of incessant minoritarian variation comes to a halt. Doubtless, their theorization

35 Ibid.

36 Ibid., 291.

${ }^{37}$ Even the second wave feminism (which criticizes the patriarchal model of society), the third wave (which endorses multivocality and inclusivity), and the fourth wave (which extends the causes of the third wave in the cyber space), must pass the process of becomingwoman.

(c) 2019 Raniel SM. Reyes

https://www.kritike.org/journal/special issue/reyes april2019.pdf

ISSN 1908-7330 
of becoming-woman receives stark criticism from feminist scholars. ${ }^{38}$ Their repudiation of the philosophy of becoming-woman is only legitimized when it is pondered as a stable concept and perspective (speaking-position), not as a molecular process of creative becoming that lies at the middle of man and woman. Moreover, becoming-woman is not tantamount to the obliteration of gender politics in particular, and all kinds of molar politics in general. It simply aims for the enhancement, differentialization, and the magnanimous call for all of us to "ungender itself [ourselves], creating a non-molarizing socius that fosters carnal invention rather than containing it." 39

The creative interplay between the molar segments of the majoritarian and the molecular flows of the minoritarian, and the virtual potentials of becoming-minoritarian are ubiquitous in all fields-gender, cultural studies, music, science, among others. In this manner, Deleuze and Guattari argue that the history of societies is not shaped by the contradiction between socioeconomic classes (which are all majoritarian or molar) as Marxists scholars would claim. Rather, it is differentialized by the molecular fissures emerging underneath rigid segments, and more importantly, it is deterritorialized by the lines of flight toward a superlative kind of creativity. For them, a micropolitics of society:

(I)s defined by its lines of flight, which are molecular. There is always something that flows or ... escapes the binary organizations, the resonance apparatus, and the overcoding machine: things that are attributed to a "change in values," the youth, women, the mad, etc. May 1968 in France was molecular, making what led up to it all the more imperceptible from the viewpoint of micropolitics. ${ }^{40}$

Deleuze and Guattari use the events behind the May 1968 struggle as a case in point. A significant problem occurs at the interstices of the said event. Being theoretical captives of obsolete philosophical theories such as psychoanalysis, Marxism, and phenomenology, the French people evaluate the said struggle through macropolitical terms. Unfortunately, they misrecognize the radical alterity or singularity of such an event irreducible to

38 One of the foremost critics of Deleuze and Guattari's philosophy in the domain of gender is Rosi Braidotti. See Rosi Braidotti, Nomadic Subjects: Difference in Contemporary Feminist Theory (New York: Columbia University Press, 1994).

${ }^{39}$ Brian Massumi, A User's Guide to Capitalism and Schizophrenia (Cambridge, MA: MIT Press, 1992), 89. See also Patton, Deleuze and the Political, 82.

${ }^{40}$ Deleuze and Guattari, A Thousand Plateaus, 216

(c) 2019 Raniel SM. Reyes

https://www.kritike.org/journal/special issue/reyes april2019.pdf

ISSN 1908-7330

(cc) BY-NC-ND 
any forms of representation and more prominently, that which opens them to a future plane of existence. According to them:

(T)he people ... understood nothing of the event because something unaccountable was escaping. The politicians, the parties, the unions, many leftists, were utterly vexed; they kept repeating over and over again that 'conditions were not ripe. It was as though they had been temporarily deprived of the entire dualism machine that made them valid spokespeople. ... A molecular flow was escaping, minuscule at first, then swelling, without, however, ceasing to be unassignable. ${ }^{41}$

At this juncture, let me emphasize that it is incorrect to think that the Deleuzian minoritarian politics only deals with perpetual and polymorphous becomings. Neither should scholars view it as an arborescent principle isolated from the sedentary frames of the majoritarian. Minoritarian and majoritarian politics operate in a continuous interplay via the principle of becoming-minoritarian, and they must remain inexorable to avoid or escape representation, marginalization, and pure anarchy. As Deleuze and Guattari underscore, "molecular escapes and movements would be nothing if they did not return to the molar organizations to reshuffle their segments, their binary distributions of sexes, classes, and parties." 42

\section{Becoming-Democratic as Becoming-Minoritarian}

\section{Becoming-Democratic as Becoming-Anti-Democratic}

The absence of a normative reference to democracy is one of the reasons why the Deleuzo-Guattarian philosophic project is hastily accused of being apolitical. Democracy does not occupy a very significant role in their political philosophy primarily because they do not understand democracy as a kind of majoritarian or normative political theory. Liberal democracy, for instance, is only discussed as one of the models of societal investment under capitalism. ${ }^{43}$ Although a straightforward mention of democracy was only

${ }^{41}$ See ibid. The legacies of May 1968 can only become pragmatic upon our critical analysis and intervention of the manifold subterranean occurrences, if not the collective decadence, which are overridden by the crowd's frenzied posture. In short, contemporary humanity and scholarship must learn the lessons it conveyed positively and negatively, especially contra various micro-fascisms that calls for micropolitical diagnosis and revaluation.

42 Ibid. 216-217.

43 See Paul Patton, Deleuzian Concepts: Philosophy, Colonization, Politics (Stanford: Stanford University Press, 2010), 162. Most of my discussions here are inspired by Patton's book. 
made in What Is Philosophy?, the democratic guise of despotic states or despotism was already articulated in Anti-Oedipus. Deleuze and Guattari write:

As for democracies, how could one fail to recognize in them the despot who has become colder and more hypocritical, more calculating, since he must himself count and code instead of overcoding the accounts? It is useless to compose the list of differences after the manner of conscientious historians .... The differences could be determining only if the despotic State were one concrete formation among others, to be treated comparatively. But the despotic State is the abstraction that is realized-in imperial formations, to be sure-only as an abstraction (the overcoding eminent unity). It assumes its immanent concrete existence only in the subsequent forms that cause it to return under other guises and conditions. ${ }^{44}$

Democracy is a kind of government that underscores the value of equality among individuals. From a more philosophical standpoint, Derrida in Politics of Friendship elucidates the historical association between democracy and friendship. Democracy, for him, is a complex term constitutive of various conceptual components such as involvement, equality, and consent in relation to the development of the majority rule. ${ }^{45}$ Ideally, in a democratic society, the voice of every individual and group is considered significant,

Capitalism's influence on democratic states authors more complex forms of dehumanizations that are aesthetically concealed by its promises of greater individual liberties, equitable social services, and ethical relations. In fact, advanced capitalism has engendered even some totalitarian and socialist states to reterritorialize into capitalist conduits.

${ }^{44}$ Deleuze and Guattari, Anti-Oedipus, 220. The association of the Marxist critical diagnosis of capitalism with the principles of distributive justice before the 1980s has contributed to the copious efforts of English-speaking scholars to synthesize Marxism and the normative principles of left-liberal political theory. Concurrent with this innovation, the French political grain gained a renewed interest to discourse on equality, human rights, and freedom. One of the contributions of these advancements to Deleuze and Guattari's career is the evolution from the problematic of the state apparatus and nomad toward the discussion on the critical relation between the universal capitalist market and virtual universality of a global democratic state. From the critique of psychoanalysis, Marxism, capitalism, and the State apparatus, the said shift from the 1980s onward widened and included engagement with existing institutions in conjunction with liberal democratic values, especially in relation to human rights and jurisprudence. All of these more manifest engagements with democratic principles and practices are articulated in What Is Philosophy? along with other interviews and essays such as his "Open Letters to Negri's Judges."

${ }^{45}$ See Jacques Derrida, Politics of Friendship, trans. by T. Collins (London: Verso, 1997).

(c) 2019 Raniel SM. Reyes

https://www.kritike.org/journal/special issue/reyes april2019.pdf

ISSN 1908-7330

(c) $\mathrm{BY}-\mathrm{NC}-\mathrm{ND}$ 
especially in relation to personal welfare, public policies, and political deliberations (such as the local and national elections). An egalitarian form of society does not arbitrarily privilege and exclude any individual, class, or group based on economic stature, religious affiliation, and cultural orientation. Although in reality, from the Ancient times until the modern period, Plato and Nietzsche, for instance, would attest that the practice of democracy is characterized by none other than a politics of oppression and degeneration regulated by the power-greedy elites. However, despite the criticism of democracy's imperfections by philosophers, it has gained more friends than foes throughout the history of political thought.

Deleuze and Guattari's project focuses on a diagnosis and critique of democracy and its pitfalls. Deleuzo-Guattarian politics may be of relevance on issues where a student's human rights are violated by his or her university authorities, where a member of the LGBTQ community is prohibited from running an administrative position in an office, and where an employee is prevented from being regularized in a company. However, while Deleuze and Guattari are still committed to the values of equality and freedom, which are known pillars of the democratic ideal, they do not subscribe to the logic of collective will, otherwise known as the rule of the majority. Minoritarian politics aspires to critically examine how laws are created and interpreted, and how minoritarians can challenge majoritarian principles in society so as to produce novel laws and relations. Moreover, minoritarian politics resuscitates desire's ability to fashion heterogeneous constellations and becomings. Democracy, as a minoritarian political principle, involves incessant agonism between conflicting opinions via experimentation and creation, thereby cultivating it into a politics of pure immanence. ${ }^{46}$ Thus, we can call this new brand of democracy as minoritarian democracy or becoming-democracy.

Minoritarian democracy, ${ }^{47}$ for example, would claim that the Universal Declaration of Human Rights issued by the United Nations should not be construed as a final document. Of course, it would only be considered as something definitive when we presuppose that human rights is an ahistorical concept, which is the fundamental assumption of traditional democracy. For minoritarian democracy, the application of the said declaration of human rights should not be performed in a 'one-size-fits-all' fashion because it would misrecognize the historico-cultural contexts and contingencies. As such, news rights or laws must be created if certain situations push our current laws to their limits. In Deleuze's interview with Negri, he claims that "it is jurisprudence that truly creates laws: this should

\footnotetext{
${ }^{46}$ See Patton, Deleuzian Concepts, 165.

${ }^{47}$ See also Deleuze and Guattari, What Is Philosophy?, 107.
} 
not be left to judges." 48 It means that the conceptualization of new laws or rights must always recognize the voices of the citizens (especially of the human rights violations victims) and their dynamics with various social factors and circumstances or what Deleuze and Guattari refer to as the people's immanent mode of existence. ${ }^{49}$

Deleuze's penchant for jurisprudence over universal rights entails his valorization of localized and open-ended creative processes that engender the emergence of novel and opportune rights. It is because jurisprudence is the creative modification of existing laws and rights to address varying and present circumstances. Such definition of jurisprudence serves as a springboard to the philosophy of becoming-revolutionary because it is faithful to the Deleuzo-Guattarian definition of philosophy as the invention of new concepts capable of counteractualizing the grain and becoming closer to life. As Deleuze argues:

To act for freedom, becoming-revolutionary, is to operate in jurisprudence when one turns to the justice system ... that's what the invention of law is ... it's not a question of applying 'the rights of man' but rather of inventing new forms of jurisprudence .... I have always been fascinated by jurisprudence, by law .... If I hadn't studied philosophy, I would have studied law, but precisely not 'the rights of man,' rather I'd have studied jurisprudence. That's what life is. There are no "rights of man," only rights of life, and so, life unfolds case by case. ${ }^{50}$

Further, Deleuze and Guattari's enigmatic relation to the idea of democracy has resulted in a division among contemporary scholars, as cogently elucidated by Patton in Deleuzian Concepts: Philosophy, Colonization, and Politics. On the one hand, Nicholas Thoburn is sympathetic to the idea that Deleuze and Guattari are pursuing an alternative democratic politics. For Thoburn, the Deleuzo-Guattarian micropolitics is an alternative to Ernesto Laclau and Chantal Mouffe's neo-Gramscian post-Marxism. ${ }^{51}$ In the chapter "The Grandeur of Marx" of the book Deleuze, Marx and Politics, Thoburn asserts that Deleuze's last book was supposed to be called The Grandeur of

\footnotetext{
${ }^{48}$ Deleuze, Negotiations, 230. See also ibid. 169.

${ }^{49}$ Deleuze and Guattari, What Is Philosophy?, 103.

50 Gilles Deleuze and Claire Parnet, "G comme Gauche," L'Abécédaire de Gilles Deleuze, avec Claire Parnet, directed by Pierre-André Boutang (Paris: DVD Editions Montparnasse, 1996).

${ }^{51}$ Cf. Patton, Deleuzian Concepts, 169. 
Marx.$^{52}$ Despite the challenges that haunt Marxism, it is still a very convincing critique of capitalism. ${ }^{53}$ Despite Deleuze and Guattari's intellectual gratitude to Marx's philosophy and their revolutionary project which diverges from traditional Marxist revolutionary struggles that focus on the emancipation of the proletariats from capitalist alienation, they focus on the liberation of individual and collective desire-production from Oedipal and capitalist totalization (schizoanalysis) and the minotarianization of codified and hierarchized principles and relations (becoming-minoritarian). In addition, their concept of revolution does not aspire for the capture of state power; rather, it seeks the crafting of new relations and subjectivity-formations by undermining all representationalist or molar codes in the society. ${ }^{54}$

Meanwhile, the scholar Philip Mengue thinks that the DeleuzoGuattarian political philosophy completely departs from democracy. Mengue thinks that democracy is either devalued or merely given a secondary importance in the Deleuzo-Guattarian political philosophy. This antipathy to democracy is based on an uncritical acceptance of the Marxist doxa prevalent among French scholars in the post-1968 period. ${ }^{55}$ Mengue argues that even though Deleuze and Guattari deserted the praxis of class struggle, their conceptualization of the relationship between modern forms of state and capital is still reliant on the principle of economic determinism. This allows them to replicate their version of the classical Marxist denunciation of liberal democracy as little more than a concession or alibi that serves only to maintain the capitalist system of exploitation and repression. ${ }^{56}$ Mengue's accusation that Deleuze's politics is devoid of any positive relation with democracy is only legitimized from the vantage point of majoritarian or normative politics. However, as I argued earlier, this is beyond the scope of their democratic politics. After discussing the specificity of Deleuzian politics, we must now confront the question: What is the place of democracy in Deleuze's political philosophy?

In relation to the aforesaid query, Mengue asserts that Deleuzian politics is devoid of any institutional space to legitimize the value of any

52 Nicholas Thoburn, Deleuze, Marx, and Politics (London: Routledge, 2003), 142.

${ }^{53}$ In relation to this, Deleuze develops his project as a kind of a politics of invention that surpasses the borders of normative politics and antagonizes the capitalist system. When Marx's philosophy of communism is creatively fused with Deleuze's politics, a new materialist ontology of the society characterized by difference and virtuality becomes a great possibility.

${ }^{54}$ At present, capital has survived the collapse of grand narrative and reconstructs its relation of production into an immanent system and force capable of configuring its own territory, limits, and overcoming. See Karl Marx and Friedrich Engels, Manifesto of the Communist Party (Beijing: Foreign Languages Press, 1973), 37; Nicholas Thoburn, "The Grandeur of Marx," in Deleuze, Marx, and Politics (London and New York: Routledge, 2003), 2.

${ }^{55}$ Philip Mengue, Deleuze et la question de la démocratie (Paris: L'Harmattan, 2004), 43.

${ }^{56}$ Ibid., 107-110. 
political exchange. This is the consequence of a political theory bereft of transcendental categories and rigid codes that would backbone political normativity. Of course, Deleuze does not deny the importance of institutional spaces and regulative principles in the forms of laws to ground manifold actions within a political community. Otherwise, their project would simply end up being a populist politics in anarchy.

This problematic necessitates us to return to my discussion of Deleuze and Guattari's triadic politics. Going back to the essay, "Who are Our Nomads Today?," Lundy claims that contrary to the general belief that Deleuze's political philosophy espouses the felicitation of absolute deterritorialization and pure lines of flight, his project is informed by an "ethics of prudence." 57 Lundy's discussion presupposes that when the molecular line metamorphoses as the governing principle of politics, political instability is of high possibility. The same is true with the molar line because the segmentarized majoritarian politics is the sphere of State philosophy and rigid molar codes - the nemesis of the nomad. For Lundy, because the nomad is the figure of transfiguration, it might be more appropriate to delegate the nomad to the perpetually shifting space in-between the molar (striated) and the molecular (supple) lines, which they call the holey space. ${ }^{58}$ This means that the Deleuzo-Guattarian politics is not simply concerned with perpetual transfiguration, polysemy, and fluidity in the same vein that it does not categorically despise the existence of certain infrastructures or institutions. Hardt and Negri support this claim in Empire:

Difference, hybridity, and mobility are not liberatory in themselves, but neither are truth, purity and stasis. The real revolutionary practice refers to the level of production. Truth will not make us free, but taking control of the production of truth will. Mobility and hybridity are not liberatory, but taking control of the production of mobility and stasis, purities and mixture is. ${ }^{59}$

The principles of difference, hybridity, and mobility, according to Hardt and Negri, are not by default revolutionary. Societal mechanisms, such as institutions, are necessary to regulate their productive processes and emancipatory potentials. Going back to Deleuzo-Guattarian politics, because

\footnotetext{
${ }^{57}$ Craig Lundy, "Who are Our Nomads Today? Deleuze's Political Ontology and the Revolutionary Problematic," in Deleuze Studies, 7:2 (2013), 1.

${ }^{58}$ Ibid., 243.

${ }^{59}$ Antonio Negri and Michael Hardt, Empire (Cambridge: Harvard University Press, 2000), 156 .

(c) 2019 Raniel SM. Reyes

https://www.kritike.org/journal/special issue/reyes april2019.pdf

ISSN 1908-7330
}

(c) BY-NC-ND 
it embodies an ethics of prudence, then there is a place for institutions that would serve as sites for political discourses, transactions, and evaluations. For example, a legal institution must be established so that the rule of law would override everyone, especially in times when the minorities are abused by the majority. But it should be noted that these principles must be derived from a multilevel and multisectoral engagements, which is an alternative to normative or transcendental authority.

With the absence of a higher authority, politics in the DeleuzoGuattarian context transforms into a vertical differentialization into the political field where dissenting opinions and political orientations are played out. ${ }^{60}$ Of course, this is a difficult challenge because the pluralistic character of the modern and contemporary world does not revolve around a single notion of a democratic state. Concurrent with the singularities of democratic states are dissenting opinions (populist, nationalist, or philosophical) regarding justice and fairness that further support the institutional structure of democracy. Philosophical or national opinions are indispensable in the local configuration of each democratic society. As Deleuze and Guattari claim in What Is Philosophy?: "In each case philosophy finds a way of reterritorializing itself in the modern world in conformity with the spirit of a people and its conception of right. The history of philosophy therefore is marked by national characteristics or rather by nationalitarianisms which are like philosophical opinions." 61

Unfortunately, advanced capitalism universalizes all singular democratic states under the axiomatic and overarching principle of global capital. As Deleuze and Guattari critically elucidate:

If there is no universal democratic State ... It is because the market is the only thing that is universal in capitalism ... capitalism functions as an immanent axiomatic of decoded flows (money, labor, products). National States are no longer paradigms of overcoding but constitute the "models of realization" of this immanent axiomatic. In an axiomatic, models do not refer back to a transcendence ... It is as if the deterritorialization of States tempered that of capital and provided it with compensatory reterritorializations. Now, models of realization may be very diverse (democratic, dictatorial, totalitarian), they may be heterogeneous, but they are nonetheless isomorphous

${ }^{60}$ See Patton, Deleuzian Concepts, 162.

${ }^{61}$ Deleuze and Guattari, What Is Philosophy?, 104. 
with regard to the world market insofar as the latter not only presupposes but produces determinate inequalities of development. That is why ... democratic States are so bound up with, and compromised by, dictatorial States that the defense of human rights must necessarily take up the internal criticism of every democracy. ${ }^{62}$

An utter debasement of democratic politics or states occurs when everything about democracy is subsumed under the axiomatic of advanced or global capitalism. As such, all the egalitarian values of democracy reterritorialize into capitalist values that benefit the capitalist system alone. In his 1990 interview with Negri, Deleuze juxtaposes the sense in which the market as a sphere of exchange of commodities and capital is universal that further with the sense in which it generates both wealth and misery and distributes these in a manner that is neither universalizing nor homogenizing. ${ }^{33}$ When there is a conflict between some fundamental political rights and the security of private property, for example, a higher priority is relegated to the latter. To be more specific, "when private property in the means of production," Patton explains, "exists alongside the absence of mechanisms to provide minimal healthcare, housing or education, the basic welfare rights of the poor are effectively suspended." ${ }^{64}$ Capitalism's supremacy over democracy only proves that "rights can save neither men nor a philosophy that is reterritorialized on the democratic State. Human rights will not make us bless capitalism." 65 In particular, human rights based on capitalist configuration will not pave the way for the birth of a new people. ${ }^{66}$ In general, democratic States that regulate them and serve as their milieu do not map a new earth.

62 Ibid., 106.

${ }^{63}$ Deleuze, Negotiations, 234, 173. It is the principle of equality and the idea that such undeserved inequalities of condition are unjust that underpin Deleuze's criticism of both capitalism and the liberal democratic states through which its control of populations is exercised. See Patton, Deleuzian Concepts, 169.

${ }^{64}$ Patton, Deleuzian Concepts, 188.

${ }^{65}$ Deleuze and Guattari, What Is Philosophy?, 107

${ }^{66}$ Deleuze asserts in Cinema 2: The Time-Image, that the "people are what is missing." See Gilles Deleuze, Cinema 2: The Time-Image, trans. by Hugh Tomlinson and Robert Galeta (Minneapolis, MN: University of Minnesota Press, 1989), 215. As such, absence is inextricably linked with the notion of a creative minority he explicates in Negotiations. The people's existence is premised on the principle of minority or minoritarian; that is why they are absent. The fabulation of the "people-to-come' - "mass-people, world-people, brain-people, chaos-people" (Deleuze, What Is Philosophy? 218)-have certain attributes in common with philosophy and art: "their resistance to death, to servitude, to the intolerable, to shame and to the present" (ibid., 110). Moreover, fabulation compensates the people's incapacity to create art. They can participate in the very act of artistic fabulation, while art fabulates by addressing itself to a virtual people. The alliance between the people and the artistic minority, and their inclusion in artistic fabulation assumes the Deleuzo-Guattarian politicization of the Bergsonian fabulation.

(c) 2019 Raniel SM. Reyes

https://www.kritike.org/journal/special issue/reyes april2019.pdf

ISSN 1908-7330

$(\mathrm{Cc}) \overline{\mathrm{BY}-\mathrm{NC}-\mathrm{ND}}$ 
Indeed, Deleuze and Guattari contend that "this people and earth will not be found in our democracies," but only in the thinking of the most untimely and radical of philosophers such as Nietzsche. ${ }^{67}$

Deleuzian politics acts as an antithesis to the numerous infractions found in capitalist-configured democracy, which Thoburn refers to as social democratic politics. ${ }^{68}$ Moreover, its anti-capitalist stance is directed toward the totalizing character of advanced capitalism that obliterates the singularities of present democratic states and subordinates all democratic principles, exchanges, and processes into the axiomatic of global capital. The variegated faces of misery it has introduced to mankind and to the world banalize human existence and numb our critical or revolutionary impulse. Although it is equipped with a self-reflexive attribute that offers the possibility of inaugurating universal history, it is a critical process that simply aspires for its internal fortification and expansion. A capitalist-configured democracy, therefore, does not provide us radical and creative means to antagonize the present state of affairs toward a people and world-to-come. It is only at this critical point, I should say, that Mengue's main argument makes sense.

\section{Becoming-Democracy and Minoritarian Becoming}

Given the various capitalist-authored injustices and democracyrelated predicaments, Parnet interrogates Deleuze in L'Abécédaire interview: what does it mean to be on the Left? Enormous poverty experienced by millions of people worldwide invalidates the belief that the good life is still possible. In several depressed places, the variegated appearances and implications of poverty such as massive death and moribund healthcare system dishearten us to find any reason for existence anymore. Being on the Left, for Deleuze, implies, "starting with the edges ... and knowing how, and say what one might, knowing that these problems that must be dealt with ... [Being on the Left] is really finding arrangements, finding world-wide assemblages." 69

In other words, starting with the edges and searching for minoritarian constellations that would aid us to critically engage with different forms of injustices (specifically poverty) entail one's adherence to the principle of becoming-minoritarian. In general, the said principle of becoming contends that the 'majority' or majoritarian rule is an abstract concept and arbitrary standard because its political identity is simply

${ }^{67}$ See ibid., 108

68 Thoburn, Deleuze, Marx, and Politics, 9, 42.

${ }^{69}$ Deleuze and Parnet, "G comme Gauche," L'Abécédaire de Gilles Deleuze, avec Claire Parnet.

(c) 2019 Raniel SM. Reyes

https://www.kritike.org/journal/special issue/reyes april2019.pdf

ISSN 1908-7330

(cc) BY-NC-ND 
grounded in a particular configuration of power and control. ${ }^{70}$ The problem behind this majority rule paradigm is that it is prone to being manipulated by any prevailing collectivity or system (capitalist system) by which a particular configuration of power and control can assume a universal dominion over things.

Becoming-minoritarian, in addition, is nonteleological and does not privilege any minority as the sole revolutionary agent of the future or the collectivity that would antagonize all forms of oppression emanating from the majoritarian rule. The rhizomatic and molecularized trajectories of revolutionary transformations and the democratization of the revolutionary agency portray becoming-minoritarian as becoming-democratic. In $A$ Thousand Plateaus, Deleuze and Guattari explain that becoming-minoritarian refers to the potentiality of an individual or groups to deviate from the majoritarian politics or the normative standards in the society and to craft novel relations and intensities. ${ }^{71}$

Becoming-minoritarian not only undermines the rigid walls of majoritarian codifications in the society. More importantly, it puts a premium on the "process" of differentializing totalized representations in the same vein that Deleuze and Guattari valorize the "schizophrenic process," instead of the schizophrenic himself or herself as articulated in Anti-Oedipus. Put differently, becoming-minoritarian empowers free and creative desiringmachines to radicalize the manifold sedentary spaces maintained by State philosophy through continuous mutations. In this manner, its interstitial distance from majoritarian politics is conditioned by its thrust of not acquiring the terrain of the majority..$^{72}$

Minoritarian politics' divergence from the majoritarian does not necessarily indicate their opposition with each other. For Deleuze and Guattari, the relation between the majoritarian and the minoritarian must be viewed in terms of difference between degree or configuration. Majoritarian standards and political activities are oftentimes fostered via democratic and legal procedures. Whereas Deleuze and Guattari perceive the majoritarian as a symbol of emptiness, for it represents no specific individual or group, they view the minoritarian as a representation of a departure from the representative politics of the majoritarian. ${ }^{73}$ Becoming-minoritarian or minoritarian politics does not propose a definitive alternative to majoritarian

70 See Patton, Deleuzian Concepts, 170.

${ }^{71} \mathrm{Cf}$. Mengue, Deleuze et la question de la démocratie, 53. For Mengue, the majoritarian democratic politics belongs to the realm of the segmentary line because it is not hospitable to becomings. In relation to political exchanges of dissenting opinions, politics, for him, must reconcile all dissenting voices toward the end.

72 Deleuze and Guattari, A Thousand Plateaus, 106

${ }^{73}$ Patton, Deleuzian Concepts, 176. 
politics. By alternative, I mean another codified molar category that would substitute the existing one. Such initiative, if pursued, simply reintroduces the old predicament disguised in a new appearance. Rather, becomingminoritarian operates alongside the majoritarian in the sense that it critically antagonizes the latter to fashion new relations, connections, and intensities. In recent years, certain legislative standards (by virtue of becomingminoritarian) already extend to nonwhites, nonmales, and non-Christians (in a nonbinary fashion) as a differentialization of the majoritarian categories of white, male, and Christian. ${ }^{74}$ In short, even normative politics in today's time has already started to configure its own concept of creativity and has opened its doors to the kaleidoscopic voices of the subalterns (as a process, not as privileged or majoritarian subjectivities).

While there are incongruities between Mengue's description of democratic politics and Deleuzo-Guattarian minoritarian politics, the latter finds a kindred spirit in William Connolly. For Connolly, democracy is a distinctive form of cultural and political practice because it allows participation in collective decisions while enabling contestation of past settlements. ${ }^{75}$ In this kind of politics, legal and institutional judgments, and convictions are always open for critical diagnosis and revision. In Deleuze's "Open Letter to Negri's Judges," he questions the legal basis of the charges against Antonio Negri, specifically "the lack of consistency in the charges themselves, the failure to follow ordinary logical principles of reasoning in the examination of evidence, and the role of the media in relation to this judicial procedure." 76 This self-critical typology of democracy undoubtedly crafts a space where even the subaltern groups and subaltern discourses are recognized in the reformulation of laws and policies. This becomes possible because this fluid politics is configured by subterranean shifts in the attitudes, sensibilities, and beliefs of people and communities. Deleuzian politics runs parallel to this democratic ethos in the sense that it challenges liberal democracy to always consider micropolitical processes, especially in the domains of decision-making and critical dialogical exchange. ${ }^{77}$

Minority becomings modify the overall configurations of different social institutions. But these modifications always work alongside the majoritarian. Hence, minoritarian politics is not an alternative, but a critical complement to majoritarian politics or normative democratic politics where individuals and societies do not wholly succumb to the molar standards of

\footnotetext{
${ }^{74}$ Of course, alongside these judicial or legal developments are cultural initiatives or complements of postcolonial theorists such as Edward Said and Gayatri Spivak.

${ }^{75}$ William Connolly, The Ethos of Pluralization (Minneapolis and London: University of Minnesota Press, 1995), 103.

${ }^{76}$ Ibid.

77 Patton, Deleuzian Concepts, 168.
} 
the majoritarian but exist in a process of unremitting mutation and/or variation. If the quantity of the ways in becoming-minoritarian depends on the number of majoritarian principles in the society, then the same applies to becoming-democratic in relation to the various forms of democracy.

Deleuze and Guattari in What Is Philosophy? ponder the principle of becoming-democratic as a becoming-revolutionary against the current state of affairs that further necessitates the invention of novel types of resistance and philosophical concepts toward a new plane of existence. The ardent call for resistance against the present is premised on philosophy's unrelenting antagonism against opinion. ${ }^{78}$ In $A$ Thousand Plateaus, additionally, Deleuze and Guattari claim that philosophy is the enemy of opinion. What is presupposed at this point is that collective and enlightened opinions matter in the agora of a democratic society. However, opinion becomes an object of censure when it is merely reduced to the voice of the majority capitulation and hence annihilates its dynamism and creativity. ${ }^{79}$ Deleuze and Guattari write: "Political decision making necessarily descends into a world of microdeterminations, attractions and desires, which it must sound out or evaluate in a different fashion. Beneath linear conceptions and segmentary decisions, quanta." 80

In countries such as the Philippines, the vicious connivance of antiintellectualism and populism has really vitiated the different sectors of the Philippine society such as education, industry, and politics. ${ }^{81}$ In the realm of politics, for instance, the anti-intellectualist and populist mindset of voters has resulted in the election of questionable representatives. This is the reason why humanities in general, and arts and philosophy in particular are indisputably underrated in this country. Although arts and philosophy cannot give us luxurious material rewards, their critical and emancipatory imports can inspire us to untiringly seek for greater causes in life and open us to the nonphilosophical aspects of life.

\footnotetext{
${ }^{78}$ See Deleuze, What Is Philosophy?, 203

${ }^{79}$ Deleuze and Guattari, What Is Philosophy?, 165.

${ }^{80}$ Deleuze and Guattari, A Thousand Plateaus, 220-221. The struggle between popular and philosophical opinions is a quintessential problem in the history of philosophy. As early as Plato's time, the prevalence of opinions undoubtedly engendered the banality of ethico-political existence of the Ancient people. Such societal debasement became extremely hostile to great thinkers who wanted to search for the truth behind the illusions provided by different opinions. The Ancient triumvirate (i.e., Socrates, Plato, and Aristotle) eventually devised their respective philosophical projects to liberate their fellowmen from the yoke of ignorance or deception.

${ }^{81}$ See Caroline Hau, "Privileging Roots and Routes: Filipino Intellectuals and the Contest over Epistemic Power and Authority," Philippine Studies: Historical and Ethnographic Viewpoints, 62:1 (2014), 29-65.

(c) 2019 Raniel SM. Reyes

https://www.kritike.org/journal/special issue/reyes april2019.pdf

ISSN 1908-7330
}

(cc) BY-NC-ND 
Like equality, fairness, and freedom, Deleuze asserts in Negotiations that philosophy is not a Power in the sense that states, capitalism, and public opinion are. According to him:

Philosophy may have its great internal battles ... but they are mock battles. Not being a power, philosophy can't bathe with the powers that be, but it fights a war without battles, a guerilla campaign against them. And it can't converse with them ... nothing to communicate, and can only negotiate. Since the powers aren't just external things, but permeate each of us, philosophy throws us all into constant negotiations with, and a guerilla campaign against, ourselves..$^{82}$

The precarious pathway for philosophical opinions and thinking to flourish in society is to actively and critically engage with existing popular opinions and scheme of things that grounds the fair or just-the political vocation of philosophy. ${ }^{83}$ What succeeds philosophy's negotiations with the powers that be is the creation of ways to confront manifold occurrences of dehumanization at present. ${ }^{84}$ In this regard, becoming-democratic as the political vocation of philosophy is counteractualizing the "liberal democratic present." By 'counteractualize,' I mean a way of articulating movements of relative deterritorialization, that is, modifications in a people's opinions in relation to equality and fairness, among others. In addition, to counteractualize entails extending democracy's actualization and relevance within contemporary societies..$^{85}$

The minoritarian subjection of the majoritarian to different types of minority-becomings has broadened the configuration of democracy. In some parts of the world, women can now join the military; minorities can now enjoy the right to suffrage, and even marginalized groups can now form party-list organizations. Likewise, public institutions and infrastructures are reconfigured to become more politically and culturally accommodating. Restaurants and fastfood chains are presently more accessible to people with disabilities; public transportation already provides reserved seats for senior citizens, and universities administered by religious institutions already accept students from different religious orientations. These are only some of the legacies of a democratic space whose political exchange is characterized

\footnotetext{
${ }^{82}$ Deleuze, Negotiations, vii. Emphasis mine.

${ }^{83}$ Cf. Paul Patton, "Becoming-Democratic," in Deleuze and Politics, ed. by Ian Buchanan and Nicholas Thoburn (Edinburgh: Edinburgh University Press, 2008), 189.

${ }^{84}$ Deleuze, Negotiations, 171.

${ }^{85}$ Cf. Patton, "Becoming-Democratic," 190.
} 
by openness, criticality, and fluidity. Such minoritarian-becomings advance one of the significant vectors of becoming-democratic in the contemporary period.

\section{Concluding Remarks}

Contemporary versions of becoming-democracy are not limited to the Deleuzian philosophical milieu. Chantal Mouffe's theorization of radical democracy is one example. In The Return of the Political, she expounds her theory of radical democracy. Informed by the diversity and complexity of current societal relations, her radical democracy project does not presuppose a universal or ahistorical subject. Rather, it is constitutive of decentered agencies, which are products of various conjunctions and disjunctions of subject positions. As Mouffe opines:

(N)o identity is ever definitively established, there always being a certain degree of openness and ambiguity in the way the different subject positions are articulated. What emerges are entirely new perspectives for political action, which neither liberalism, with its idea of the individual who only pursues his or her own interest, nor Marxism, with its reduction of all subject positions to that of class, can sanction, let alone imagine. ${ }^{86}$

Another illustration of becoming-democracy can be found in Rosi Braidotti's philosophy of Posthumanism. It is informed by various ecological catastrophes and the threat of extinction posed by technological advancements (artificial intelligence). Primarily, her brand of critical posthumanism antagonizes the humanist tradition and western philosophy's disregard of the zoe (nonhuman life). These predicaments are aggravated by the intricacies and perils posed by technological advancements. Moreover, her critical posthumanism critically diagnoses advanced capitalism's recomposition of man, i.e., in creatively appropriating these humanist and global crises toward a pseudo-united humanity, which is merely a capitalist ploy to convert life itself into a capital.

The different vectors or ways of becoming-democratic or becomingminoritarian (as becoming-revolutionary) portrayed in and outside the Deleuzian territory, would always receive critical oppositions from the very

13.

${ }^{86}$ Chantal Mouffe, The Return of the Political (London and New York: Verso, 1993), 12-

(c) 2019 Raniel SM. Reyes

https://www.kritike.org/journal/special issue/reyes april2019.pdf

ISSN 1908-7330

(cc) BY-NC-ND 
principle they attempt to undermine or differentialize. The axiomatic of capitalism, which is always operating and overcoming itself, would craft its version of counteractualization to respond to our minoritarian struggle against several expressions of dehumanization, injustice, and inequality. ${ }^{87}$ Once the dynamic, agonistic, and minoritarian features of political relations and the affirmative conviction of philosophers to counteractualize the intolerable present vanish, everything would be totalized by advanced capitalism, and more human miseries would plague the world. More importantly, the invention of concepts toward a people-to-come and the "conjunction of philosophy or of the concept with the present milieu" 88 would just be an empty vision.

$$
\begin{array}{r}
\text { Department of Philosophy } \\
\text { Research Center for Culture, Arts, and Humanities } \\
\text { The Graduate School } \\
\text { University of Santo Tomas, Philippines }
\end{array}
$$

\section{References}

Bonta, Mark and John Protevi, Deleuze and Geophilosophy: A Guide and Glossary (Edinburgh: Edinburgh University Press, 2004)

Braidotti, Rosi, Nomadic Subjects: Difference in Contemporary Feminist Theory (New York: Columbia University Press, 1994).

Connolly, William, The Ethos of Pluralization (Minneapolis and London: University of Minnesota Press, 1995).

Deleuze, Gilles, Cinema 2: The Time-Image, trans. by Hugh Tomlinson and Robert Galeta (Minneapolis, MN: University of Minnesota Press, 1989).

Negotiations, trans. by Martin Joughin (New York: Columbia University Press, 1995).

Deleuze, Gilles and Claire Parnet, Dialogues, trans. by Hugh Tomlinson and Barbara Habberjam (London: Athlone Press, 1987). Dialogues II, rev. ed., trans. by Hugh Tomlinson and Barbara Habberjam (New York: Columbia University Press, 2007).

\footnotetext{
${ }^{87}$ In Anti-Oedipus, Deleuze and Guattari lucidly describe capitalism's immanence and creativity: "the strength of capitalism indeed resides in the fact that its axiomatic is never saturated, that it is always capable of adding a new axiom to the previous ones. Capitalism defines a field of immanence and never ceases to fully occupy this field. But this deterritorialized field finds itself determined by an axiomatic, in contrast to the territorial field determined by primitive codes." Deleuze and Guattari, Anti-Oedipus, 250.

${ }^{88}$ Deleuze, What Is Philosophy?, 100.
} 
"G comme Gauche," L'Abécédaire de Gilles Deleuze, avec Claire Parnet, directed by Pierre-André Boutang (Paris: DVD Editions Montparnasse, 1996).

Deleuze, Gilles and Felix Guattari, A Thousand Plateaus: Capitalism and Schizophrenia, trans. by Brian Massumi (Minneapolis: University of Minnesota Press, 1987).

What is Philosophy?, trans. by Hugh Tomlinson and Graham Burchell (New York: Columbia University Press, 1994).

Derrida, Jacques, Politics of Friendship, trans. by T. Collins (London: Verso, 1997).

Foucault, Michel, Preface to Gilles Deleuze and Felix Guattari, Anti-Oedipus: Capitalism and Schizophrenia, trans. by Robert Hurley, Mark Seem, and Helen R. Lane (Minneapolis, MN: University of Minnesota Press, 1983).

Guattari, Felix, Chaosophy: Texts and Interviews 1972-1977, ed. by Sylvère Lotringer, trans. by David L. Sweet, Jarred Becker, and Taylor Adkins (Los Angeles, CA: Semiotext(e), 2009).

Hau, Caroline, "Privileging Roots and Routes: Filipino Intellectuals and the Contest over Epistemic Power and Authority," Philippine Studies: Historical and Ethnographic Viewpoints, 62:1 (2014).

Lundy, Craig, "Who are Our Nomads Today? Deleuze's Political Ontology and the Revolutionary Problematic," in Deleuze Studies, 7:2 (2013).

Marx, Karl and Friedrich Engels, Manifesto of the Communist Party (Beijing: Foreign Languages Press, 1973).

Massumi, Brian, A User's Guide to Capitalism and Schizophrenia (Cambridge, MA: MIT Press, 1992).

Translator's Foreword to Gilles Deleuze and Felix Guattari, $A$ Thousand Plateaus: Capitalism and Schizophrenia, trans. by Brian Massumi (Minneapolis: University of Minnesota Press, 1987).

Mengue, Philip, Deleuze et la question de la démocratie (Paris: L'Harmattan, 2004).

Mouffe, Chantal, The Return of the Political (London and New York: Verso, 1993).

Negri, Antonio and Michael Hardt, Empire (Cambridge: Harvard University Press, 2000).

Patton, Paul, "Becoming-Democratic," in Deleuze and Politics, ed. by Ian Buchanan and Nicholas Thoburn (Edinburgh: Edinburgh University Press, 2008). Deleuze and the Political (London: Routledge, 2000). Deleuzian Concepts: Philosophy, Colonization, Politics (Stanford: Stanford University Press, 2010). 
"Foucault and Normative Political Philosophy," in Foucault and Philosophy, ed. by Timothy O'Leary and Christopher Falzon (Oxford: Wiley-Blackwell).

Thoburn, Nicholas, Deleuze, Marx, and Politics (London: Routledge, 2003).

"The Grandeur of Marx," in Deleuze, Marx, and Politics (London and New York: Routledge, 2003). 